\title{
43. CARBONATE AND PORE-WATER GEOCHEMISTRY OF PELAGIC CAPS AT LIMALOK AND LO-EN GUYOTS, WESTERN PACIFIC ${ }^{1}$
}

\author{
Carsten Israelson, ${ }^{2}$ Bjørn Buchardt, ${ }^{2}$ Janet A. Haggerty, ${ }^{3}$ and Paul N. Pearson ${ }^{4}$
}

\begin{abstract}
Pelagic sediments accumulated on Limalok and Lo-En guyots as they sank below the wave base. Limalok Guyot contains 140 $\mathrm{m}$ of pelagic sediments that range in age from the early Miocene to the Holocene. Lo-En Guyot contains approximately $150 \mathrm{~m}$ of pelagic sediments of late Oligocene to Holocene age. Ten different geochemical parameters were measured in an attempt to evaluate the potential use of the sediments as a geochemical recorder of the environment. It was found that, although the pelagic caps consist of well-preserved planktonic foraminifers, mixing of sediments during or shortly after deposition precludes highresolution paleoceanographic studies. The original pore-water composition is modified by interactions with the sediment and possibly by seawater at a postdepositional time.
\end{abstract}

\section{INTRODUCTION}

\section{Background}

The purpose of the present study is to evaluate pelagic caps on western Pacific guyots as geochemical recorders and to assess their suitability for paleoceanographic studies.

The guyots studied are Limalok and Lo-En guyots, which belong to the Marshall Island group of seamounts. Pelagic sediments accumulated on these guyots as they slowly sank below the wave base after the drowning of the carbonate platform. This means that the pelagic sediments were deposited well above the carbonate compensation depth (CCD) and consist almost solely of planktonic foraminifers and nannofossil ooze with a very low clay content.

Four kinds of geochemical parameters were studied in these sediment samples: carbonate concentration, element ratios $(\mathrm{Sr} / \mathrm{Ca}, \mathrm{Mg}$ ) $\mathrm{Ca})$, stable isotopes $\left(\delta^{18} \mathrm{O}\right.$ and $\left.\delta^{13} \mathrm{C}\right)$, and radiogenic isotopes $\left({ }^{87} \mathrm{Sr} /\right.$ ${ }^{86} \mathrm{Sr}$ ). Furthermore, four kinds of parameters were studied in the pore water samples: element concentration, stable isotopes $\left(\delta^{18} \mathrm{O}\right.$ and $\left.\delta^{2} \mathrm{H}\right)$, radiogenic isotopes $\left({ }^{87} \mathrm{Sr} /{ }^{86} \mathrm{Sr}\right)$, and short-chain organic acids.

\section{Previous Studies}

Legs 143 and 144 are the first Ocean Drilling Program (ODP) expeditions to drill through all of the lithologies of Pacific guyots, including the volcanic pedestal. Only Leg 144 recovered pelagic cap sediment; therefore, literature on the geochemical properties of pelagic caps is sparse. Sedimentation and erosion processes on nearby Horizon Guyot have been described by Lonsdale et al. (1972). As with the guyots studied in this paper, Horizon Guyot has a pelagic cap that consists of Tertiary nannofossil and planktonic foraminifer ooze. Lonsdale et al. (1972) found that the pelagic sediment had suffered continuing erosion that had winnowed away the fine components of the sediment. Bed load transport of the remaining foraminiferal sand created regular trains of ripple and dunes.

\footnotetext{
${ }^{1}$ Haggerty, J.A., Premoli Silva, I., Rack, F., and McNutt, M.K. (Eds.), 1995. Proc. $O D P$, Sci. Results, 144: College Station, TX (Ocean Drilling Program).

${ }^{2}$ Geological Institute, University of Copenhagen, Øster Voldgade 10, DK-1350 Copenhagen K. Denmark.

${ }^{3}$ Department of Geosciences, University of Tulsa, 600 South College Avenue, Tulsa, OK 74104, U.S.A.

${ }^{4}$ Department of Earth Sciences, University of Cambridge, Downing Street, Cambridge, CB2 3EQ. United Kingdom. (Present address: Department of Geology, Wills Memorial Building. University of Bristol, Queens Road, Bristol BS8 IRJ, United Kingdom.)
}

\section{SITE SUMMARIES AND SEDIMENTS}

The sites studied are located on Limalok (Site 871) and Lo-En (Site 872) guyots in the western Pacific Ocean (see site map preceding the title page). Pelagic sediments were recovered in all three cases using the advanced hydraulic piston corer (APC). In general, the foraminifer or nannofossil foraminifer ooze was soupy upon recovery. This carbonate ooze had a very high water content and contained only a small percentage of clay, unlike the majority of pelagic carbonate sequences drilled by the Deep Sea Drilling Project (DSDP) or ODP. Liquefaction appeared to occur where the sediments were disturbed, although some sedimentary structures were recognized in the cores (Premoli Silva, Haggerty, Rack, et al., 1993). Downhole contamination caused by caving from the top of the hole was a problem for biostratigraphic age assignment in several cases (Pearson, this volume).

\section{Limalok Guyot (Site 871)}

Limalok Guyot is located toward the southern end of the eastern Ratak Chain of seamounts (see site map preceding the title page) and is the best studied of the two guyots described herein. Site 871 $\left(5^{\circ} 33.4^{\prime} \mathrm{N}, 172^{\circ} 20.7^{\prime} \mathrm{E}\right)$ was drilled through the central and thickest part of the pelagic cap at a water depth of $1255 \mathrm{~m}$. Of the two holes cored (871A and $871 \mathrm{~B})$, the most complete recovery of pelagic sediment $(90.7 \%)$ was obtained in Hole $871 \mathrm{~A}$, which also provided all of the samples from Site 871 analyzed in this study. Refusal occurred at 139.5 meters below seafloor (mbsf) as the piston core reached a black, laminated iron-manganese crust. The manganese crust overlies an Eocene limestone platform.

The pelagic sediments accumulated at Limalok Guyot (Site 871) can be divided into two subunits (Premoli Silva, Haggerty, Rack, et al., 1993). Subunit IA covers the interval from 0 to $25.1 \mathrm{mbsf}$. This unit comprises homogeneous nannofossil foraminifer ooze. Age assignments from both planktonic foraminifers and nannofossils indicate a Pleistocene to upper Pliocene biostratigraphic age (Premoli Silva, Haggerty, Rack, et al., 1993; Pearson, this volume). Subunit IB ranges from 25.1 to $139.5 \mathrm{mbsf}$ and consists of homogeneous foraminifer ooze with a winnowed, well-sorted, medium-sized sand texture. The unit is dominated by planktonic foraminifers ( $95 \%)$; nannofossils make up less than $5 \%$ of the unit. Biostratigraphic dating of Subunit IB indicates an age of early to middle Miocene (Pearson, this volume). However, micropaleontological and Sr-isotope studies have demonstrated that sedimentation was episodic and reworking was common (Israelson et al. and Pearson, both in this volume). The lower Miocene interval was particularly unsuited for biostratigraphic dating, not only 
because of upward sediment reworking of zonal marker species, but also because of the lack of well-defined zone fossils (Pearson, this volume). It was not possible to establish a detailed foraminifer zonation below 80.5 mbsf (Cores $144-871 \mathrm{~A}-9 \mathrm{H}$ to $-15 \mathrm{H}$ ).

\section{Lo-En Guyot (Site 872)}

Site $872\left(10^{\circ} 05.6^{\prime} \mathrm{N}, 162^{\circ} 52.0^{\prime} \mathrm{E}\right)$ was drilled in the central and thickest portion of Lo-En Guyot at a water depth of $1084 \mathrm{~m}$. Of the two adjacent holes ( $872 \mathrm{~A}$ and $872 \mathrm{C}$ ), Hole $872 \mathrm{C}$ was most complete, with $97.7 \%$ recovery of pelagic sediment. Therefore, all analyzed samples, are from this hole. APC refusal occurred at $141.7 \mathrm{mbsf}$, at the boundary between upper Oligocene pelagic sediments and altered basalt. The contact between altered basalt and Oligocene sediment consists of partly lithified fragments of white foraminifer ooze.

The pelagic sediments at Lo-En Guyot have been divided into two subunits based on the downhole decrease in nannofossil abundance and a corresponding coarsening of the sediment texture (Premoli Silva, Haggerty, Rack, et al., 1993). Subunit IA (interval from 0 to 32.9 mbsf) consists of foraminifer ooze and is interbedded with subordinate, pale brown nannofossil foraminifer ooze in vague layers, which are several centimeters to tens of centimeters thick. Foraminifer biostratigraphic data suggest a Pleistocene-Pliocene age for Subunit IA. Age determination based on planktonic foraminifers was problematic because of the severe fragmentation of the foraminifer tests (Pearson, this volume), although nannofossils provided detailed biostratigraphic zonation (Watkins, this volume). Subunit IB covers the interval from 32.9 to $141.7 \mathrm{mbsf}$ and consists of soupy homogeneous foraminifer ooze with less than $5 \%$ nannofossils. This interval ranges in age from late Oligocene to late Miocene, although biostratigraphic age assignments were difficult because of the frequent reworking and the presence of several hiatuses in the unit (Pearson, this volume).

\section{SAMPLES AND ANALYTICAL PROCEDURES}

Two kinds of sediment samples were analyzed: bulk sediment samples and samples consisting of single species of planktonic foraminifer. To determine carbonate concentrations, samples were run two ways: (1) after leaching to remove salt and (2) unleached. For single-species samples, individually picked specimens of single foraminifer species were used. Obvious downhole contaminants were avoided by analyzing only species presumed to be alive at the time of sediment deposition. Downhole contaminants were often Pleistocene species. Interstitial pore waters were retrieved from 5- to $10-\mathrm{cm}$-long, whole-round or half-round core sections. Pore waters were extracted using the technique described in Buchardt et al. (this volume) and Premoli Silva, Haggerty, Rack, et al. (1993).

\section{Carbonate Concentration}

Carbonate concentration was determined using titration. Every sample analyzed was measured twice. The results shown in Figures 1 and 2 are the average values of these two measurements.

\section{$\mathrm{Ca}, \mathrm{Sr}$, and $\mathrm{Mg}$ Concentrations}

For concentrations of $\mathrm{Ca}, \mathrm{Sr}$, and $\mathrm{Mg}, 100 \mathrm{mg}$ of leached sediment was dissolved. Element concentrations were determined using a Perkin-Elmer Atomic Absorption Spectrophotometer Model 460. The measurement techniques applied were the two standard methods, and reproducibility was estimated to be $\pm 5 \%$.

\section{Oxygen and Carbon Isotopes of Carbonates}

Both bulk samples and single-species planktonic foraminifers were analyzed. Bulk-sample analyses were conducted at the Danish Center of Isotope Geology, University of Copenhagen, whereas singlespecies foraminifer analyses were made at the University of Cam- bridge. For information on technical procedures for single-species foraminifer analyses, see Pearson and Shackleton (this volume). For the bulk-sample analyses, approximately $20 \mathrm{mg}$ of sediment was used. Every sample was analyzed twice, as duplicate runs included complete chemical processing of each sample. For ${ }^{13} \mathrm{C} /{ }^{12} \mathrm{C}$ and ${ }^{18} \mathrm{O} /{ }^{16} \mathrm{O}$ determinations, a Finnigan MAT 250 triple-collector mass spectrometer was used. Sample compositions were measured against the laboratory standard (LEO) and were calculated as PDB values $\left(\delta^{18} \mathrm{O}\right)$. Precision for oxygen and carbon isotope determinations, expressed as \pm standard deviation for 10 preparations of standard carbonate, is better than $\pm 0.07 \%$ on the delta scale for both oxygen and carbon isotopes.

\section{Sr Isotopes}

Only single species of planktonic foraminifers were used for the $\mathrm{Sr}$-isotope analyses presented in this study. Isotope ratios were measured in the dynamic mode on a VG Sector 54 thermal ionization mass spectrometer at the Danish Center for Isotope Geology, University of Copenhagen. The average value of the NBS-987 standard, measured throughout the 6-month period of the Leg 144 study was ${ }^{87} \mathrm{Sr} /{ }^{86} \mathrm{Sr}=$ 0.710257 , with a standard deviation of $\pm 14.8 \times 10^{-6}(N=45)$. The error quoted for all samples in this study is the average difference between sample duplicates, which is $19.8 \times 10^{-6}$. For more information on these analytical procedures, see Israelson et al. (this volume).

\section{Organic Geochemistry}

The preservation of organic matter in the pelagic sediment was generally poor. Determination of the carbon isotope composition of organic material was only made on samples from Limalok Guyot (Site 871).

\section{Pore-water Isotopes}

Oxygen isotope analysis were conducted at the Department of Geophysics, Niels Bohr Institute, University of Copenhagen according to the standard $\mathrm{CO}_{2}^{-}$equilibration technique described in Buchardt et al. (this volume). Hydrogen isotope analyses were performed at the Danish Center for Isotope Geology at the Geological Institute, University of Copenhagen. Oxygen and hydrogen isotope ratios were analyzed in a Finnigan MAT 250 gas mass spectrometer and are reported as $\delta$-values relative to Standard Mean Ocean Water (SMOW).

Pore-water strontium isotope analyses were performed at Department of Earth Sciences, University of Cambridge. During the course of this work, the NBS 987 standard yielded ${ }^{87} \mathrm{Sr} /{ }^{86} \mathrm{Sr}=0.710254 \pm 2$, $4 \times 10^{-6}(N=23)$. The difference between this value and the value measured at the Danish Center for Isotope Geology is only 0.000003 , which is less than the internal error of each individual analysis. Thus, the $\mathrm{Sr}$-isotope values for the pore waters and the sediment samples are comparable. For a detailed description of Sr-isotope analytical techniques used on pore waters, see Buchardt et al. (this volume).

\section{Pore-water Organic Acids}

Interstitial water samples used for organic acid determinations were treated with an ammonium salt to inhibit bacterial degradation of organic compounds (Haggerty and Fisher, this volume). Organic acids were determined using ion exclusion chromatography (IEC: Dionex 2000 i series chromatograph, S1 separator, membrane suppressor, 800 $\mu \mathrm{m}$ octanesulfonic acid eluant, tetrabutylammonium hydroxide regenerant, conductivity detection) as described in Haggerty and Fisher (1992, 1994).

\section{RESULTS Limalok Guyot}

All geochemical parameters used in this study were measured throughout the Limalok pelagic cap. Of the 10 parameters shown in 

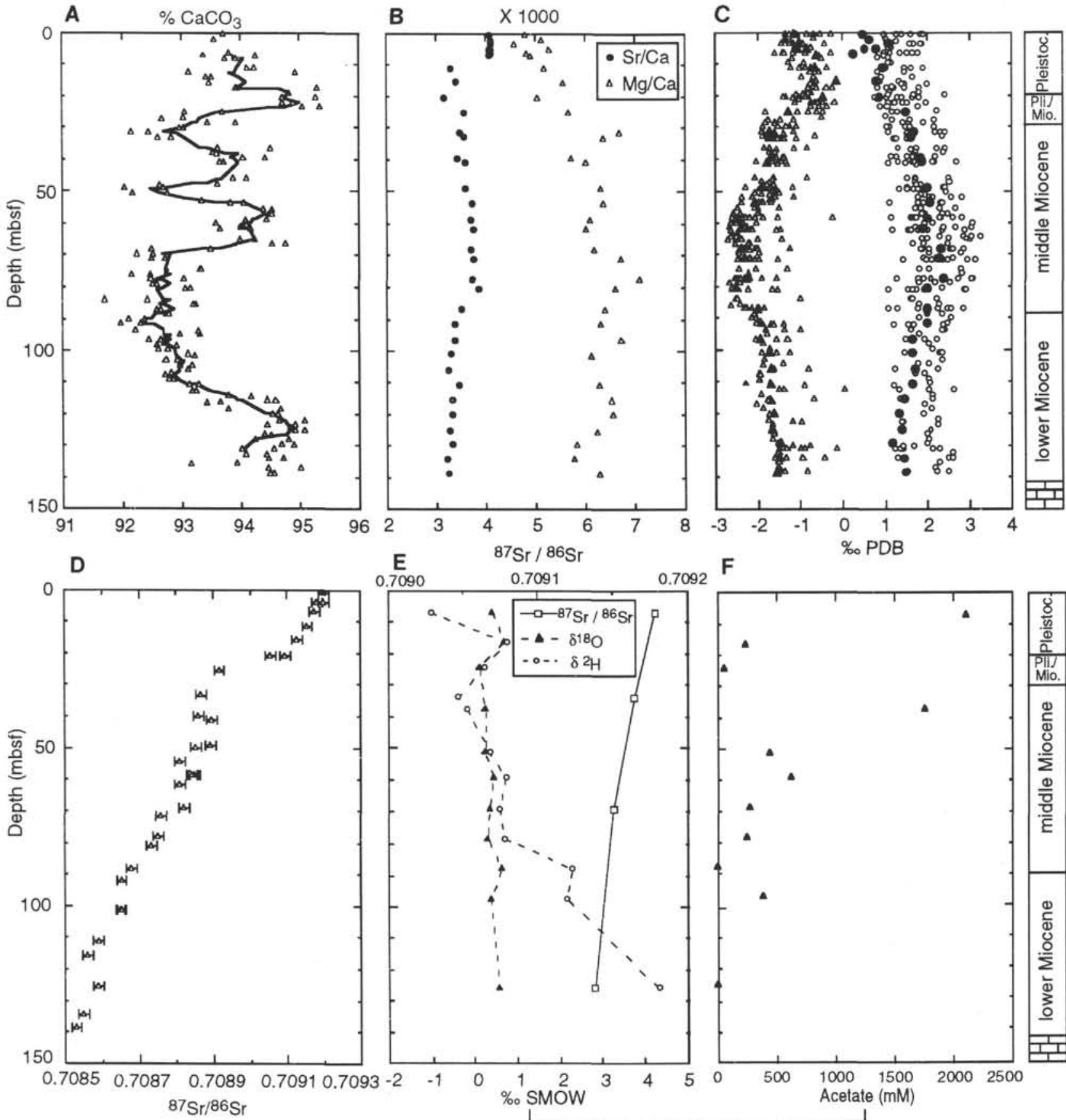

$F$

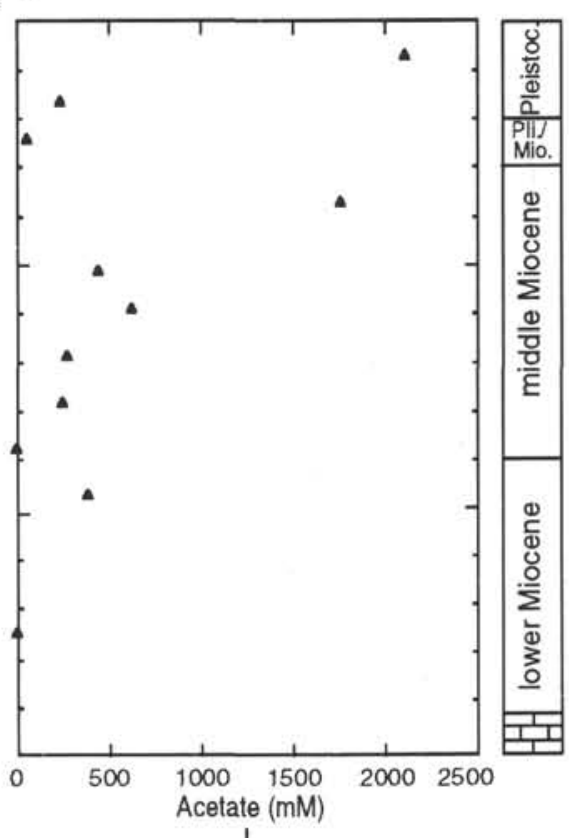

Pore-water

Figure 1. A-F. Summary of geochemical parameters measured at Limalok Guyot (Site 871). In Figure 1A, the line represents a 5-point running average. In Figure $1 \mathrm{C}$, triangles $=\delta^{18} \mathrm{O}$, and circles $=\delta^{13} \mathrm{C}$ values (filled triangles and circles represent values determined on bulk sediment samples). Time reference is from the planktonic foraminifer stratigraphy (Pearson, this volume).

Figure 1, carbonate content, element concentration, and bulk stable isotope values are not published elsewhere in this volume. Singlespecies stable isotopes are from Pearson and Shackleton (this volume); Sr isotopes are from Israelson et al. (this volume); pore-water data are from Buchardt et al. (this volume); and organic acid data are from Haggerty and Fisher (this volume).

The carbonate contents ( $\mathrm{wt} \% \mathrm{CaCO}_{3}$ ) exhibit a decreasing trend from 140 to $110 \mathrm{mbsf}$, remain constant from 110 to $70 \mathrm{mbsf}$, and are more variable above 70 mbsf.

Element concentrations of $\mathrm{Sr}$ and $\mathrm{Mg}$ are shown as $\mathrm{Sr} / \mathrm{Ca}$ and $\mathrm{Mg} / \mathrm{Ca}$ ratios in Figure $1 \mathrm{~B}$ and Table 1 . The pelagic sediments can be divided into two distinct units based on the $\mathrm{Sr} / \mathrm{Ca}$ ratios. The first unit, extending from 0 to $10 \mathrm{mbsf}$, is characterized by $\mathrm{Sr} / \mathrm{Ca}$ ratios that are very consistent at approximately 0.0041 . Between Samples 144-871 A$1 \mathrm{H}-\mathrm{CC}, 10-11 \mathrm{~cm}$ (7.2 mbsf), and -12H-3, 69-71 cm (11.19 mbsf), a major shift to lower $\mathrm{Sr} / \mathrm{Ca}$ ratios takes place. From $11.19 \mathrm{mbsf}$ to the bottom of the hole, ratios vary slightly between 0.0032 and 0.0038 (Table 1). $\mathrm{Mg} / \mathrm{Ca}$ ratios show a downhole increasing trend (Fig. 1B), with values around 0.005 in the uppermost $10 \mathrm{~m}$ of the hole. From 10 to $50 \mathrm{mbsf}, \mathrm{Mg} / \mathrm{Ca}$ ratios increase downhole to a value of approximately 6 at 50 mbsf. From 50 mbsf to the bottom of Hole $871 \mathrm{~A}$, no trend in $\mathrm{Mg} / \mathrm{Ca}$ ratios is visible. 
Table 1. Bulk sample $\mathrm{Mg} / \mathrm{Ca}, \mathrm{Sr} / \mathrm{Ca}, \delta^{13} \mathrm{C}$, and $\delta^{18} \mathrm{O}$ values from Limalok (Hole 871A) and Lo-En (Hole 872C) guyots.

\begin{tabular}{|c|c|c|c|c|c|}
\hline $\begin{array}{l}\text { Core, section } \\
\text { interval }(\mathrm{cm})\end{array}$ & $\begin{array}{l}\text { Depth } \\
\text { (mbsf) }\end{array}$ & $\begin{array}{l}\mathrm{Mg} / \mathrm{Ca} \\
\times 1000\end{array}$ & $\begin{array}{l}\mathrm{Sr} / \mathrm{Ca} \\
\times 1000\end{array}$ & $\begin{array}{c}\delta^{13} \mathrm{C} \\
(\% \circ \mathrm{PDB})\end{array}$ & $\begin{array}{c}\delta^{18} \mathrm{O} \\
\text { (\%o PDB) }\end{array}$ \\
\hline $\begin{array}{l}144-871 \mathrm{~A}- \\
1 \mathrm{H}-1,68-70 \\
1 \mathrm{H}-2,68-71 \\
1 \mathrm{H}-3,68-72 \\
1 \mathrm{H}-4,68-73 \\
1 \mathrm{H}-5,68-74 \\
1 \mathrm{H}-\mathrm{CC}, 10-11 \\
2 \mathrm{H}-3,69-71 \\
2 \mathrm{H}-6,69-71 \\
3 \mathrm{H}-3,69-71 \\
3 \mathrm{H}-3,69-71 \\
3 \mathrm{H}-6,69-71 \\
3 \mathrm{H}-6,69-71 \\
4 \mathrm{H}-4,69-71 \\
4 \mathrm{H}-5,69-71 \\
5 \mathrm{H}-3,69-71 \\
5 \mathrm{H}-4,69-71 \\
6 \mathrm{H}-3,69-71 \\
6 \mathrm{H}-6,69-71 \\
7 \mathrm{H}-3,70-72 \\
7 \mathrm{H}-5,70-72 \\
8 \mathrm{H}-5,69-71 \\
8 \mathrm{H}-3,69-72 \\
9 \mathrm{H}-3,70-72 \\
9 \mathrm{H}-5,69-71 \\
10 \mathrm{H}-3,70-72 \\
10 \mathrm{H}-6,70-72 \\
11 \mathrm{H}-3,72-74 \\
11 \mathrm{H}-6,69-71 \\
12 \mathrm{H}-3,72-74 \\
12 \mathrm{H}-6,72-74 \\
13 \mathrm{H}-3,69-71 \\
13 \mathrm{H}-6,69-71 \\
14 \mathrm{H}-3,69-71 \\
14 \mathrm{H}-6,69-71 \\
15 \mathrm{H}-3,69-71 \\
15 \mathrm{H}-6,69-71\end{array}$ & $\begin{array}{r}0.68 \\
2.18 \\
3.68 \\
5.18 \\
6.58 \\
7.20 \\
11.19 \\
15.69 \\
20.69 \\
20.69 \\
25.19 \\
25.19 \\
31.69 \\
33.19 \\
39.69 \\
41.19 \\
49.19 \\
53.69 \\
58.70 \\
61.70 \\
68.19 \\
71.19 \\
77.70 \\
80.69 \\
87.20 \\
91.70 \\
96.72 \\
101.19 \\
106.22 \\
110.72 \\
115.69 \\
120.19 \\
125.19 \\
129.69 \\
134.19 \\
138.69\end{array}$ & $\begin{array}{l}4.81 \\
5.13 \\
4.59 \\
5.29 \\
4.84 \\
4.91 \\
5.19 \\
5.58 \\
5.06 \\
\\
5.68 \\
\\
6.72 \\
6.39 \\
5.74 \\
6.04 \\
6.34 \\
6.38 \\
6.10 \\
6.03 \\
6.21 \\
6.74 \\
7.11 \\
6.62 \\
6.48 \\
6.34 \\
6.75 \\
6.14 \\
2.78 \\
6.21 \\
6.54 \\
6.64 \\
6.26 \\
5.81 \\
5.79 \\
6.31\end{array}$ & $\begin{array}{l}4.08 \\
4.10 \\
4.12 \\
4.10 \\
4.12 \\
4.09 \\
3.30 \\
3.40 \\
3.16 \\
\\
3.57 \\
3.48 \\
3.56 \\
3.45 \\
3.58 \\
3.59 \\
3.73 \\
3.70 \\
3.77 \\
3.71 \\
3.77 \\
3.74 \\
3.86 \\
3.52 \\
3.39 \\
3.37 \\
3.30 \\
3.26 \\
3.46 \\
3.32 \\
3.33 \\
3.26 \\
3.32 \\
3.21 \\
3.25\end{array}$ & $\begin{array}{l}0.48 \\
0.65 \\
1.11 \\
0.80 \\
0.25 \\
0.97 \\
0.81 \\
0.88 \\
1.67 \\
1.50 \\
1.59 \\
1.69 \\
1.62 \\
1.83 \\
1.87 \\
1.99 \\
2.06 \\
2.00 \\
1.89 \\
2.32 \\
2.27 \\
2.38 \\
2.00 \\
1.99 \\
1.99 \\
1.66 \\
1.66 \\
1.71 \\
1.66 \\
1.46 \\
1.34 \\
1.41 \\
1.19 \\
1.46 \\
1.50\end{array}$ & $\begin{array}{l}-1.12 \\
-1.33 \\
-1.00 \\
-0.81 \\
-0.59 \\
-0.63 \\
-0.12 \\
-0.45 \\
-2.02 \\
-1.26 \\
-0.72 \\
-1.70 \\
-1.72 \\
-1.66 \\
-1.78 \\
-1.89 \\
-2.04 \\
-2.45 \\
-2.38 \\
-2.38 \\
-2.29 \\
-2.23 \\
-2.49 \\
-2.00 \\
-1.91 \\
-1.92 \\
-1.72 \\
-1.66 \\
-1.69 \\
-1.69 \\
-1.60 \\
-1.64 \\
-1.45 \\
-1.49 \\
-1.54\end{array}$ \\
\hline $\begin{array}{l}144-872 \mathrm{C}- \\
11 \mathrm{H}-3,10-12 \\
11 \mathrm{H}-6,10-12 \\
13 \mathrm{H}-3,10-12 \\
13 \mathrm{H}-6,10-12 \\
14 \mathrm{H}-3,10-12 \\
14 \mathrm{H}-7,10-12 \\
15 \mathrm{H}-3,10-12 \\
15 \mathrm{H}-6,10-12 \\
16 \mathrm{H}-3,10-12 \\
16 \mathrm{H}-6,10-12 \\
17 \mathrm{X}-2,9-11\end{array}$ & $\begin{array}{r}97.10 \\
101.05 \\
108.60 \\
112.50 \\
118.00 \\
123.30 \\
127.40 \\
130.85 \\
132.10 \\
135.60 \\
141.09\end{array}$ & $\begin{array}{l}3.46 \\
3.38 \\
3.10 \\
2.93 \\
2.68 \\
2.70 \\
2.82 \\
2.77 \\
2.86 \\
3.10 \\
3.18\end{array}$ & $\begin{array}{l}3.10 \\
3.17 \\
2.96 \\
3.02 \\
2.94 \\
3.13 \\
2.97 \\
3.11 \\
2.99 \\
2.94 \\
2.89\end{array}$ & $\begin{array}{l}2.40 \\
1.68 \\
2.04 \\
2.32 \\
1.80 \\
1.49 \\
1.48 \\
1.20 \\
1.17 \\
1.42\end{array}$ & $\begin{array}{l}-1.78 \\
-1.38 \\
-1.18 \\
-1.28 \\
-1.57 \\
-1.01 \\
-0.90 \\
-0.66 \\
-0.46 \\
-0.67\end{array}$ \\
\hline
\end{tabular}

A compilation of oxygen and carbon isotope data is shown in Figure 1C. For single species of foraminifers, 29 different species were analyzed (readers are referred to Pearson and Shackleton [this volume] for a more detailed discussion of multi-species isotope data, with respect to evolutionary patterns in planktonic foraminifers). Figure 1C shows that bulk sediment analyses and analyses of single foraminifer samples have the same overall variation in both $\delta^{18} \mathrm{O}$ and $\delta^{13} \mathrm{C}$ throughout the core. An exception to this observation is noted in the uppermost $10 \mathrm{~m}$ of the core, where bulk $\delta^{13} \mathrm{C}$ values are about $0.5 \%$ lower than single species foraminifer values. This interval coincides with the interval of elevated $\mathrm{Sr} / \mathrm{Ca}$ ratios (Fig. 1B).

The Sr-isotope results are shown in Figure 1D. To avoid analyzing downhole contaminants, samples consisted of between 20 and 100 individually picked specimens of a single foraminifer species that was presumed to have lived at the time of deposition of the sediment. The Sr-isotope values show a general decreasing trend from presentday seawater $\left({ }^{87} \mathrm{Sr} /{ }^{86} \mathrm{Sr}=0.7092\right)$ at the top of the hole to early Miocene seawater values at $140 \mathrm{mbsf}\left({ }^{87} \mathrm{Sr} /{ }^{86} \mathrm{Sr}=0.7085\right)$. The data, however, show several trend reversals and much scatter around the general trend. One major hiatus in sedimentation can be observed at approximately $20 \mathrm{mbsf}$. For a more detailed discussion about sediment reworking and $\mathrm{Sr}$-isotope ages, see Israelson et al. (this volume).

Total organic carbon (TOC) was measured in 10 cases. The low TOC values of $<0.5 \%$ indicate that oxidation of organic matter took place during or after deposition. Alternatively, it could indicate very low primary productivity (Premoli Silva, Haggerty, Rack, et al., 1993). The organic matter present in Hole $871 \mathrm{~A}$ is mainly autochthonous and consists of linings from foraminifers (Fenner, this volume). The $\delta^{13} \mathrm{C}$ values vary from $-22 \%$ to $-26 \%$ and show no systematic variation downhole (Table 2).

The results of pore-water analyses are shown in Figures $1 \mathrm{E}$ and $\mathrm{F}$. The $\mathrm{Sr}$ isotopes show a weak downhole trend, from higher modern seawater values $(0.70918)$ toward lower late Pleistocene values at the bottom of the hole (0.70914). No general trend in oxygen and hydrogen isotope values is visible in the uppermost $80 \mathrm{~m}$ of the hole. Hydrogen isotopes show a clearly increasing trend, from values of about 1 in the interval from 80 to 130 mbsf to values of approximately 4.5 at 130 mbsf. No clear correlation between pore-water acetate concentration and isotopes is visible. A local concentration maximum of acetate occurs at $37.5 \mathrm{mbsf}$, with one value as high as $1764 \mu \mathrm{m}$. The remainder of the samples have acetate concentrations typically in excess of $250 \mu \mathrm{m}$.

\section{Lo-En Guyot}

At Lo-En Guyot (Site 872), carbonate concentration data were obtained from the entire pelagic cap, whereas other sediment geochemical data were mostly obtained from the lowermost portion of the pelagic cap of the guyot. Studies of the Lo-En Guyot pelagic cap were concentrated on the lower $50 \mathrm{~m}$ of the cap because this interval contains an upper Oligocene sequence that was not present at Limalok Guyot. In Figure 2A, the results of analyses from both desalted and bulk samples are shown. One can see differences between these two types of samples on the order of $4 \%-6 \%$ in $\% \mathrm{CaCO}_{3}$. Both data sets record a slight downhole decreasing trend in carbonate concentration.

No trends in element concentrations of $\mathrm{Sr}, \mathrm{Ca}$, and $\mathrm{Mg}$ are visible. Both $\mathrm{Sr} / \mathrm{Ca}$ and $\mathrm{Mg} / \mathrm{Ca}$ ratios are approximately equal to 0.003 .

Oxygen and carbon isotope compositions strongly covary in the lower part of the pelagic cap (Fig. 2C). From $100 \mathrm{mbsf}$ to the bottom of the pelagic cap, $\delta^{18} \mathrm{O}$ values increase from approximately $-2 \%$ to $-0.8 \%$ PDB. In the same interval, $\delta^{13} \mathrm{C}$ values decrease from about $2.5 \%$ to $1 \%$ PDB.

Sr-isotope measurements are shown in Figure 2D. All samples shown in this figure are picked single-species foraminifers. There is a clearly decreasing trend from early Miocene values $\left({ }^{87} \mathrm{Sr} /{ }^{86} \mathrm{Sr}=\right.$ $0.7086)$ at about $100 \mathrm{mbsf}$, to late Oligocene values $(0.7080)$ at about 141.09 mbsf.

Pore-water $\mathrm{Sr}$-isotope values decrease from early Pleistocene values $(0.7090)$ near the sedimentary surface at Site 872 , to middle Miocene values at about $45 \mathrm{mbsf}$. Decreasing $\mathrm{Sr}$-isotope values seem to correlate with elevated hydrogen isotope values $\left(\delta^{2} \mathrm{H}\right)$ and organic acid concentration (Figs. 2E and 2F).

The hydrogen isotope values increase from approximately $1 \%$ SMOW at $45 \mathrm{mbsf}$ to a maximum of $6.3 \%$ at $81 \mathrm{mbsf}$. A peak in acetate concentration of $3563 \mu \mathrm{m}$ occurs at $52.9 \mathrm{mbsf}$, with the concentration in the remaining samples typically in excess of $300 \mu \mathrm{m} . \delta^{18} \mathrm{O}$ values remain constant at a value around $1 \%$ SMOW throughout the hole.

\section{DISCUSSION}

Sedimentological and biostratigraphical studies have already shown that the sedimentation of pelagic sediments on western Pacific guyots is episodic and that reworking is common (Lonsdale et al., 1972; Premoli Silva, Haggerty, Rack, et al., 1993; Israelson et al. and Pearson, both in this volume). In general, these studies have shown that sediments are winnowed and that the finer fraction of the sediments has been physically removed, probably by ocean currents. An exception occurs in the upper $20 \mathrm{~m}$ of the pelagic cap at Limalok Guyot (Site 871), which contains a fine fraction of nannofossils. In the following discussion, we will assess the significance and impacts of these sedimentologic processes on the geochemical composition of the sediment. 

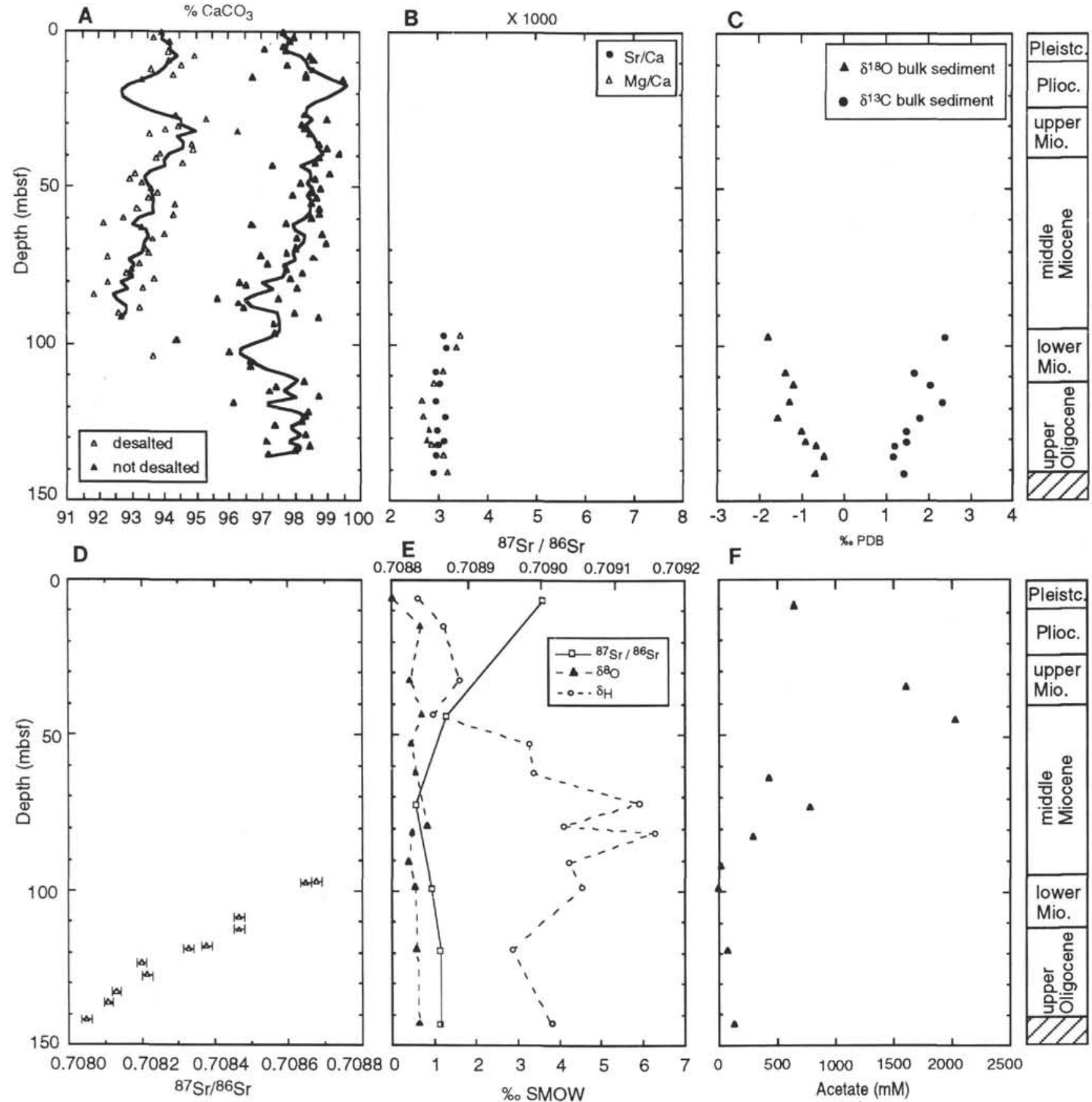

$\mathbf{F}$
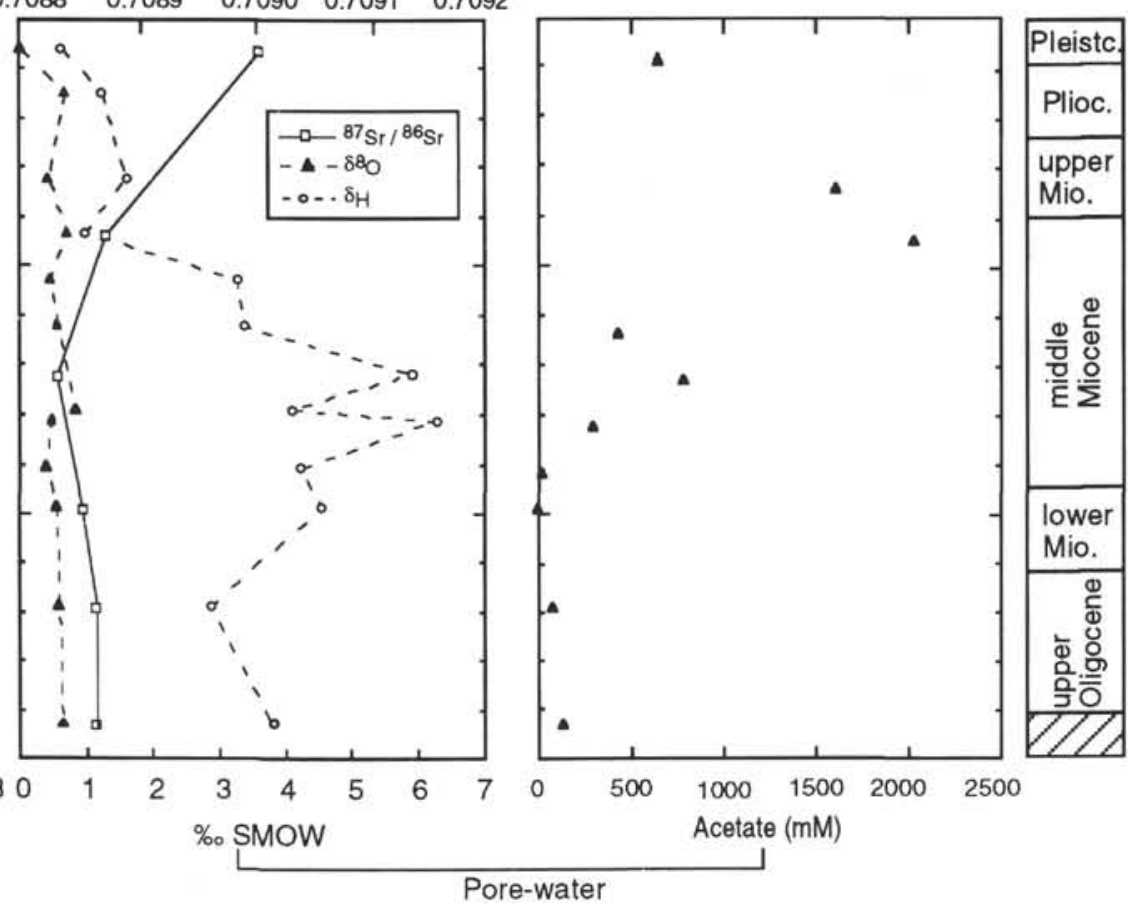

Figure 2. A-F. Summary of geochemical parameters measured at Lo-En Guyot (Site 872). In Figure 2A, the line represents a 5-point running average. Time reference is from planktonic foraminifer stratigraphy (Pearson, this volume).

\section{Sediments}

The variation in percent calcium carbonate is an indicator of the quantity of different noncarbonate materials in the sediment. We found that there was a systematic difference in carbonate content between samples that were leached to remove salt and those samples where salts were not removed (Figs. $1 \mathrm{~A}$ and $2 \mathrm{~A}$ ). The salt-related difference in carbonate is between 3 and $4 \mathrm{wt} \%$ (Fig. 2A). However, the relative variations in the weight percentage of calcium carbonate are the same for both the leached and unleached samples. Leached samples contain $1-4 \mathrm{wt} \%$ of material that is neither carbonate nor salt. The TOC is generally less than $0.5 \%$ at any given depth, and siliceous microfossils are practically absent, with even less biosiliceous material than organic material (Premoli Silva, Haggerty, Rack, et al., 1993; Fenner, this volume). Aeolian dust is normally less than $1 \mathrm{wt} \%$ of the sediment. The remaining 1\%-3\% may consist of $\mathrm{Mn}$ and $\mathrm{Fe}$ oxides or other unidentified minerals such as opal, zeolites, and hydroxides (Rack et al., this volume). No systematic variations in the weight percentage of calcium carbonate were observed in the pelagic caps of the Leg 144 guyots. The most complete carbonate concentration record is from Limalok Guyot (Site 871), where some general patterns can be recognized. Apparently, the interval with the most constant wt $\% \mathrm{CaCO}_{3}$ (Site $871,70-110$ mbsf) correlates with the interval of most continuous sedimentation and less mixing of sediments 
Table 2. Carbon isotope composition of organic materials at Limalok Guyot (Hole 871A).

\begin{tabular}{ll}
\hline $\begin{array}{c}\text { Core, section, } \\
\text { interval }\end{array}$ & $\delta^{13} \mathrm{C}$ \\
\hline 144-871A- & \\
1-CC & -24.67 \\
2-CC & -23.24 \\
3-CC & -22.70 \\
$4-C C$ & -24.11 \\
5-CC & -23.31 \\
8-CC & -24.55 \\
9-CC & -25.47 \\
10-CC & -25.87 \\
11-CC & -22.20 \\
12-CC & -22.59 \\
\hline
\end{tabular}

(Israelson et al. and Pearson, both in this volume). From 0 to $70 \mathrm{mbsf}$, large variations in wt $\% \mathrm{CaCO}_{3}$ occur. The $\mathrm{Sr}$ isotopes and the biostratigraphic studies suggest that several hiatuses in sedimentation and mixing of sediments are found in the same interval (Israelson et al. and Pearson, both in this volume).

Generally, elemental concentrations of $\mathrm{Sr}$ and $\mathrm{Mg}$, determined from bulk samples taken at the two sites studied, are higher than the values normally found in planktonic foraminifers (Figs. $1 \mathrm{~B}$ and $2 \mathrm{~B}$ ) (Graham et al., 1982; Renard, 1986). Graham et al. (1982) found that Cenozoic planktonic foraminifers have $\mathrm{Sr} / \mathrm{C}$ a values between 0.0009 and 0.0016 , as compared with the values between 0.003 and 0.004 found at Site 871 and 872 . This can be explained by the presence of a component of nannofossils in the bulk sediments. The even higher $\mathrm{Sr}$ concentration in the upper $10 \mathrm{~m}$ of Site 871 (where $\mathrm{Sr} / \mathrm{Ca}$ ratios are remarkably constant and are about 0.001 higher than for the rest of the record) coincide with the transition in lithology from foraminifer ooze to nannofossil foraminifer ooze. The elevated $\mathrm{Sr} / \mathrm{Ca}$ ratios can be explained by higher $\mathrm{Sr}$ concentrations in the finer fraction (i.e., nannofossils). We think that the variations in $\mathrm{Sr} / \mathrm{Ca}$ and $\mathrm{Mg} / \mathrm{Ca}$ ratios found in pelagic cap sediments reflect changes in sediment composition rather than paleoceanographic changes in seawater $\mathrm{Sr}$ and $\mathrm{Mg}$ concentrations. Future studies of $\mathrm{Sr} / \mathrm{Ca}$ and $\mathrm{Mg} / \mathrm{Ca}$ ratios in pelagic caps should concentrate on picked foraminifers in order to detect paleoceanographically controlled changes such as those described by Graham et al. (1982).

The stable isotope measurements presented in this paper do not offer a temporal resolution that is suitable for detailed paleoceanographic studies (Pearson and Shackleton, this volume). However, the close correlation between $\delta^{18} \mathrm{O}$ and $\delta^{13} \mathrm{C}$ values in the Miocene have previously been described by other authors (Savin et al., 1985; Miller et al., 1991; Wright et al., 1992; Hodell and Vayavananda, 1994). Savin et al. (1985) recognized a shift toward lighter $\delta^{18} \mathrm{O}$ values of approximately $1 \% 0$ in the middle Miocene. This shift is visible at approximately $60 \mathrm{mbsf}$ at Site 871 (Fig. 1D). Furthermore, the shift is accompanied by a corresponding shift toward heavier $\delta^{13} \mathrm{C}$ values. Because of reworking and mixing of the sediments, this isotopic shift is smoothed out over an interval of at least $10 \mathrm{~m}$. Therefore, it is not as clear as the same isotope event recognized, for example, at DSDP Site 289 (Savin et al., 1985). Altogether, changes in stable isotopic composition over time scales of several millions of years are recognized in the pelagic cap sediments. Fine-scale variations over periods of less than 1 m.y., as described in Wright et al. (1992), cannot be recognized at these sites.

At Limalok and Lo-En guyots (Figs. 1D and 2D), the Sr-isotope records show a general downhole decreasing trend from Holocene to late Oligocene values. The records also display several trend reversals and much scattering of data points, which is not expected, as compared to other Oligocene and Neogene Sr-isotope records (DePaolo, 1986; Hess et al., 1989; Hodell et al., 1991; Miller et al., 1991; Hodell and Woodruff, 1994; Oslick et al., 1994). The Sr-isotope measurements shown in this study were all made on single-species foraminifers and, thus, we assume that all downhole contaminants were avoided. We suggest, therefore, that the scattering and trend reversals of Sr-isotope data are caused only by reworking processes that mix older and younger sediments

\section{Pore Water}

In general, the pelagic cap sediments have a porosity of approximately $70 \%$ (Premoli Silva, Haggerty, Rack, et al., 1993). Furthermore, the sediments were very soupy upon recovery, and much movement of sediment within the core liner was observed. Therefore, we expected that the pore water was mixed within the length of a core and that contamination from modern seawater may have occurred.

Modern equatorial seawater has $\delta^{18} \mathrm{O}$ and $\delta^{2} \mathrm{H}$ values of about $0 \%$ SMOW (Epstein and Mayeda, 1953). Any deviation from these porewater values indicates either the presence of ancient seawater or a reaction between the pore water and the sediment. Modern Sr-isotope values are found to be around 0.7092 (Palmer and Edmond, 1989) and Neogene seawater has ${ }^{87} \mathrm{Sr} /{ }^{86} \mathrm{Sr}$ values of between 0.7083 and 0.7092 .

Potential sources of the complex organic precursors for the acetate in the pore waters of the pelagic cap sediments include (1) circulation of overlying seawater into the pelagic cap or (2) organic material deposited with the carbonate sediments. If circulation of seawater through the pelagic cap occurs, it is unlikely to be an important source for either organic acids (e.g., from acetate) or their more complex precursors. Although the exact identities of the acid precursor compounds are presently unknown, they are likely to be high molecular weight materials of sparse aqueous solubility and, hence, are unlikely to be transported by circulating seawater. The source of the complex organic precursors is most likely autochthonous organic material in the carbonate sediment, such as organic linings from foraminifers (Haggerty and Fisher, this volume).

A local concentration maximum occurs in the organic acids at approximately 25 to $50 \mathrm{mbsf}$ at both sites, which coincides with physical changes in the sediment that are related to hiatuses, depositional changes, or both of these processes (Pearson, this volume; Haggerty and Fisher, this volume). If contamination by seawater had occurred, a relationship between the depositional conditions and the organic acids would not exist for both drill sites. Furthermore, a systematic shift in the radiogenic strontium isotopic values and $\delta^{2} \mathrm{H}$ values (Figs. $1 \mathrm{E}$ and $2 \mathrm{E}$ ) from modern seawater values for Site 871 $\left({ }^{87} \mathrm{Sr} /{ }^{86} \mathrm{Sr}=0.70918\right.$ to $0.70914, \delta^{2} \mathrm{H}=1$ to 4.5$)$ and Site $872\left({ }^{87} \mathrm{Sr} /{ }^{86} \mathrm{Sr}\right.$ $=0.70900$ to $0.70886, \delta^{2} \mathrm{H}=1$ to 4.5 ) with increasing sub-bottom depth indicates a decreasing contribution to the interstitial waters from the overlying seawater during the APC coring operation.

If constant advection of seawater through the pelagic cap occurred, the organic acid data presented in Haggerty and Fisher (this volume) and the hydrogen isotope data do not support present-day activity. If active advection of seawater into the pelagic cap is occurring, then the local concentration maximum of acetic acid at 25 to 50 mbsf should not exist (Figs. 1F and 2F). Also, an antithetic variation is present between acetate concentrations and hydrogen isotopic compositions with depth at Sites 871 and 872 , although the relationship is not consistent for all data from these sites.

\section{CONCLUSIONS}

We evaluated the pelagic caps of two western Pacific Ocean guyots as potential geochemical recorders. Although the pelagic caps contain a well-preserved planktonic foraminifer fauna, sediment mixing makes it difficult to conduct high-resolution geochemical and paleoceanographic studies. Carbonate concentration and elemental ratios of $\mathrm{Sr} / \mathrm{Ca}$ and $\mathrm{Mg} / \mathrm{Ca}$ generally reflect the composition of sediments, which consist of almost $100 \%$ marine calcite. The oxygen, carbon, and strontium isotopic compositions of these sediments show some general trends known from the Oligocene and Neogene records but without the same details found in other deep-sea records. Porewater isotopic compositions and organic acid concentration are inter- 
preted as evidence of modification of the original ancient seawater through diffusion with time, occasional lateral or advect circulation, interaction with the sediments, or a combination of these.

\section{REFERENCES $*$}

Craig, H., 1957. Isotopic standards for carbon and oxygen correction factors for mass spectrometric analysis of $\mathrm{CO}_{2}$. Geochim. Cosmochim. Acta, 12:133-149.

DePaolo, D.J., 1986. Detailed record of the Neogene $\mathrm{Sr}$ isotopic evolution of seawater from DSDP Site 590B. Geology, 14:103-106.

Epstein, S., and Mayeda, T., 1953. Variation of ${ }^{18} \mathrm{O}$ content of waters from natural sources. Geochim. Cosmochim. Acta, 4:213-224.

Graham, D.W., Bender, M.L., Williams, D.F., and Keigwin, L.D., Jr., 1982. Strontium-calcium ratios in Cenozoic planktonic foraminifera. Geochim. Cosmochim. Acta, 46:1281-1292.

Haggerty, J.A., and Fisher, J.B., 1992. Short-chain organic acids in interstitial waters from Mariana and Bonin forearc serpentines: Leg 125. In Fryer, P. Pearce, J.A., Stokking, L.B., et al., Proc. ODP, Sci. Results, 125: College Station, TX (Ocean Drilling Program), 387-395.

1994. Short-chain organic acids in interstitial waters from the Tonga arc-trench system, Leg 135. In Hawkins, J., Parson, L., Allan, J., et al., Proc. ODP, Sci. Results, 135: College Station, TX (Ocean Drilling Program), 709-714.

Hess, J., Stott, L.D., Bender, M.L., Kennett, J.P., and Schilling, J.-G., 1989. The Oligocene marine microfossil record: age assessments using strontium isotopes. Paleoceanography, 4:655-679.

Hodell, D.A., Mueller, P.A., and Garrido, J.R., 1991. Variations in the strontium isotopic composition of seawater during the Neogene. Geology, 19:24-27.

Hodell, D.A., and Vayavananda, A., 1994. Middle Miocene paleoceanography of the western equatorial Pacific (DSDP Site 289) and the evolution of Goborotalia (Fohsella). Mar. Micropaleontol., 22:279-310.

Hodell, D.A., and Woodruff, 1994. Variations in the strontium isotopic ratio of seawater during the Miocene: stratigraphic and geochemical implications. Paleoceanography, 9:405-426.
Lonsdale, P., Normark, W.R., and Newman, W.A., 1972. Sedimentation and erosion on Horizon Guyot. Geol. Soc. Am. Bull., 83:289-315.

Miller, K.G., Feigenson, M.D., Wright, J.D., and Clement, B.M., 1991. Miocene isotope reference section, Deep Sea Drilling Project Site 608: an evaluation of isotope and biostratigraphic resolution. Paleoceanography, 6:33-52.

Oslick, J.S., Miller, K.G., and Feigenson, M.D., 1994. Oligocene-Miocene strontium isotopes: Stratigraphic revision and correlation to an inferred glacioeustatic record. Paleoceanography, 9:427-443.

Palmer, M.R., and Edmond, J.M., 1989. The strontium isotope budget of the modern ocean. Earth Planet. Sci. Lett., 92:11-26.

Premoli Silva, I., Haggerty, J., Rack, F., et al., 1993. Proc. ODP, Init. Repts., 144: College Station, TX (Ocean Drilling Program).

Renard, M., 1986. Pelagic carbonate chemostratigraphy $\left(\mathrm{Sr}, \mathrm{Mg},{ }^{18} \mathrm{O},{ }^{13} \mathrm{C}\right)$. Mar. Micropaleontol., 10:117-164.

Savin, S.M., Abel, L., Barrera, E., Hodell, D.A., Keller, G., Kennett, J.P., Killingley, J.S., Murphy, M., and Vincent, E., 1985. The evolution of Miocene surface and near-surface marine temperatures: oxygen isotopic evidence. In Kennett, J.P. (Ed.), The Miocene Ocean: Paleoceanography and Biogeography. Mem.-Geol. Soc. Am., 163:49-82.

Wright, J.D., Miller, K.G., and Fairbanks, R.G., 1992. Early and middle Miocene stable isotopes: implications for deepwater circulation and climate. Paleoceanography, 7:357-389.

\footnotetext{
- Abbreviations for names of organizations and publication titles in ODP reference lists follow the style given in Chemical Abstracts Service Source Index (published by American Chemical Society).
}

\author{
Date of initial receipt: 4 August 1994 \\ Date of acceptance: 4 January 1995 \\ Ms 144SR-050
}

